\title{
Invasive species identification by quadrat study in Berhampore Girls' College, Murshidabad campus and establishment of plant rescue centre within the campus
}

\author{
Ankush Pal ${ }^{1}$, Malay Mandal ${ }^{2}$, Biplab Bandyopadhyay ${ }^{3}$, Mitu De $^{4}$ and Santi Ranjan Dey ${ }^{5}$ \\ ${ }^{1}$ Assistant Professor, Dept of Botany, Berhampore Girls' College, Berhampore, Murshidabad, India \\ ${ }^{2}$ Contractual Whole Time Teacher, Department of Botany, Berhampore Girls' College, Murshidabad, India \\ ${ }^{3}$ Assistant Professor, Dept. of Botany, Krishnanath College, Berhampore, Murshidabad. India \\ ${ }^{4}$ Associate Professor, Dept. of Botany, Gurudas College, Narkeldanga, Kolkata, India \\ ${ }^{5}$ Assistant Professor, Dept. of Zoology, Rammohan College, Kolkata, India \\ ${ }^{5}$ Formerly Assistant Professor \& Head, Dept. of Zoology, Berhampore Girls' College, Murshidabad, India \\ ${ }^{*}$ Correspondence E-mail : srdey1@rediffmail.com
}

\begin{abstract}
With the increase in urbanization, studies focusing on urban ecology have developed rapidly. The plant community composition maybe disturbed due to both external and internal factors. Weeds are valuable agro-ecosystem components since they provide services complementing those obtained from crops. Ecosystem recovery from anthropogenic disturbances, either without human intervention or assisted by ecological restoration, is increasingly occurring worldwide. Plant rescues centre are usually areas which are left undisturbed for ecological restoration to take place. In this investigation quadrat method was used to determine the species composition. Coexistence and competition both are affected directly by the number of individuals in the community. Frequency, relative frequency, density and abundance were calculated to characterize the community as a whole. For the data the invasive plant species were identified. For ecological restoration some indigenous plant species were introduced within the plant rescue centre.
\end{abstract}

Keywords: Plant rescue centres, ecological restoration, invasive species, quadrat method.

\section{Introduction}

Plant genetic resource is the key component of any ecosystem. An important component of any ecosystem is the species it contains. Species also serves as good indicators of the ecological condition of a system (Morgenthal et al., 2001). For any development to be sustainable; conservation and use of genetic diversity must be at its core. Genetic diversity means all the species in the agroecosysytems, both invasive and non invasise. Although weeds are not intentionally sown, weed species are well adapted to environments dominated by humans and have been associated with crop production since the origins of agriculture (Harlan, 1992). The plants we call weeds do a vital job in ecosystems: they quickly establish in, protect, and restore soil that has been left exposed by natural and human-caused disturbances.

The role of weeds can be seen in very different ways depending on one's perspective, from an agro-ecosystem point of 
view, weeds are perceived as unwanted plants able to compete for limited resources, reducing crop yield, and make the use of large amounts of human labor and technologies necessary in order to avoid even greater crop losses (Moolani et al., 1966). However, weeds can be viewed as valuable agro-ecosystem components since they provide services complementing those obtained from crops (Liebman et al., 2001).

In agriculture and horticulture, humans replace the native climax vegetation with a suite of domesticated plant species chosen for their value as food, fodder, fiber, and fuel. Most agricultural systems severely reduce the diversity of the plant community and impose some form of repeated disturbance designed to maintain conditions favorable to growth of the chosen crop species. With the increase in urbanization, studies focusing on urban ecology have developed rapidly in recent years (Celesti-Grapow 2006).

Floristic composition is determined by environmental factors (Ayyappan and Parthasarathy, 1999). The plant community composition maybe disturbed due to both external and internal factors. The disturbance frequently implicated in the spread of invasive exotic plants (Hobbs and Humphries 1995). Pickett and White (1985) have defined disturbance as ....any relatively discrete event in time that disrupts ecosystem, community, or population structure and changes resources, substrate availability, or the physical environment. Larson in 2003 reported that there were differences both in the susceptibility of the disturbance classes to invasion and in the distributions of native weeds and exotic species among the disturbance classes. The vegetation in the disturbed areas does not reflect a naturally evolved species composition, but rather a mixture of small remnant patches dominated by native plants patches of largely invasive weedy alien plants, and areas of mixed native and non native plants (lqbal et al., 2008). All over the world, natural habitats are being degraded.

\section{Anthropogenic disturbances within the college campus:}

Earlier institutional campuses were usually devoid of any developmental activities and pollution and so had undisturbed natural vegetation and seasonal flowering plantation. But over the years more and more developmental work has been undertaken by the college administration. New buildings are being built, old buildings being renovated. The college premises have solar lights fitted along the lanes, roads connecting different buildings are being constructed. Construction material has being dumped in the open spaces on top of the natural vegetation, the weeds. After the construction material is remove there is a competition among the different species to gain dominance. It is a common feature for the invasive species to get a competitive edge over the indigenous flora. This is reflected in higher frequency among the invasive species.

\section{Invasive species}

About $40 \%$ of the Indian flora is alien, of which $25 \%$ are invasive species (Chen and Kang, 2003). Invasive Species constitutes the second most serious threat to biodiversity habitat destruction (Corlett, 1988). Some of the invasive plants are reported to have medicinal values too (Jana, 2016). Adverse and beneficial both effects are found in case of invasive plant species. Invasive plant species makes endemic species defenseless, uncompetitive, and may result in world's ecosystem dominated by few competitive, 'super-species.'

\section{Plant rescue centres for Ecosystem recovery and recovery debt}

Ecosystem recovery from anthropogenic disturbances, either without human intervention or assisted by ecological restoration, is increasingly occurring worldwide. Recently, Moreno-Mateos et al. (2017) coined the concept 'recovery debt', clearly a close relative of the ecosystem service debt (Isbell et al. 2015), and gave it significance as "the interim reduction of biodiversity and biogeochemical functions occurring during ecosystem recovery". As ecosystems progress through recovery, it is important to estimate any resulting deficit in 
biodiversity and functions (Moreno-Mateos et al., 2017).

Plant rescues centre are usually areas where anthropogenic disturbances have occurred in the past. At present the area was left undisturbed for ecological restoration to take place. In the college campus areas where construction material was dumped were earmarked as the plant rescue centre. If there is a pre dominance of invasive species then some indigenous plants are introduced to provide healthy completion with the invasive species.

\section{Materials and Methods}

Study site: Berhampore Girls' College was established in 1946. It is the first government sponsored college in the state of West Bengal. The institution was founded by Smt. Amiya Rao, an eminent scholar and wife of the then District Collector Sri B.G.Rao, as a seat for the advancement of women's education and uplift in this predominantly agricultural and backward belt of the state. It is affiliated to the University of Kalyani. The Berhampore Girls' College campus in Mursidabad district, West Bengal, India is large, with a size of 523560.20 sq. $\mathrm{ft}$. located in the heart of the Berhampore city.

The study was in the campus of Berhampore Girls' College, Berhampore, Murshidabad. It was conducted between the years 2015-2017.

\section{Methodology : Quadrat method}

Quadrats are used in many different scientific disciplines like vegetation assessment, including plant density, plant frequency and plant biomass. Frequency is highly influenced by the size and shape of the quadrats used. The area that is chosen for study must not be so big that it cannot be sampled adequately, or so small that the habitat is difficult for sampling.

For immobile organisms such as plants or for very small and slow-moving organisms plots called quadrats may be used to determine population size and density. Each quadrat marks off an area of the same size typically, a square area within the habitat. A quadrat can be made by staking out an area with sticks and string or by using a wood, plastic, or metal square placed on the ground. After setting up quadrats, researchers count the number of individuals within the boundaries of each one. Multiple quadrat samples are performed throughout the habitat at several random locations, which ensures that the numbers recorded are representative for the habitat overall.

\section{Sampling procedures}

Plant diversity study was undertaken to check and document the floral diversity in the campus.

Quadrat Size: Quadrat size is an important consideration in quadrat frequency sampling. The size of the quadrat influences the probability of each species occurring within the quadrat.

Determination of the Minimal size of the quadrat: This was determined at the onset of the investigation following standard procedures. A series of quadrats was made in a nested design and data recorded. The species area curve was used to determine the minimal plot size needed to survey the community of the study area adequately. The minimal size of the quadrat for the study of the vegetation in the college campus was determined to be $50 \mathrm{cms} \times 50 \mathrm{cms}$. In the college campus 10 (Ten) quadrats were set up.

\section{Quantitative Structure of Plant Community}

Coexistence and competition both are affected directly by the number of individuals in the community. Frequency, relative frequency, density and abundance were calculated to characterize the community as a whole. All the species occurring in each quadrat was noted and their numerical count was carried out.

\section{Plant species identification}

Samples of species that were not directly identified on the field were collected on pressers and transported to herbarium of Department of Botany, Gurudas College, Kolkata for identification. Local names of plants were also collected. Data collected from quadrat sampling was arranged in spreadsheet software (EXCEL) and analysed using formulae below to determine the relative 
frequency, density and abundance of the floral components.

\section{Frequency}

Frequency can be defined as the degree of uniformity of the occurrence of individuals of a species within a plant community. Frequency is expressed as the percentage occurrence of individuals of a species in a number of observations. It indicates the homogeneity of dispersion of the individuals of a species in the community and is determined as follows:

$\%$ frequency $=$ Number of sampling units in which the species occurred / Total number of sampling units studied $\times 100$

The estimate of frequency depends upon the size of the sampling unit. A very small sampling unit underestimates the frequency of widely spaced individuals, while a large sampling unit overestimates the frequency.

\section{Density}

Density represents the numerical strength of the species in the community. Plants grow at varying distance in respect with each other. The number of plants in a unit area gives an idea of its density. The density of various species in a community varies in time and space and affects the community structure.

Density gives an idea of competition. If density is more, it means there is more degree of competition between the individuals of the species. Density is expressed as number of individuals per unit area and is calculated as follows:

Density $=$ Total number of individuals of the species in all the sampling units / Total number of sampling units studied

\section{Abundance}

Abundance is also calculated like density but in this case, only those quadrats are considered for calculation where a species actually occurs.

Abundance $=$ Total no. of individual of the species in all the sampling units / No .of quadrate per units in which they occur

\section{Results and Discussions}

In the study the results reveals that field observation data indicates that total of 45 (Forty five) species of plants. Communities may be identified and recognized by several features that may be quantitative. Quantitative characters are those that can be measured, e.g. density, abundance, frequency. These values can be expressed as absolute or as relative values. Frequency is an important parameter of vegetation which reflects the spread, distribution or dispersion of a species in a given area. Species diversity, relative frequency, density and abundance of individual species recorded in Table 1. .

From the Table 1 data it is observed that some of the plants found during the quadrat study were invasive species. Literature on invasive species was consulted viz. Sudhakar Reddy, 2008; Jana, 2016.

List of invasive species and place of origin are given in Table 2. Many of the invasive species have been naturalized in our climatic conditions so well that they are a threat to the growth of native species. 31 species out of the total 45 species observed were invasive species.

An area was designated as Plant Rescue centres within the college campus. It was cordoned off so that no material for construction work was dumped there. The rescue centre was an area which was totally undisturbed by anthropogenic disturbances. 14 indigenous plant species were introduced in this area. These plants were allowed to grow with the invasive species. Adjacent to this area a medicinal plant garden, called 'Madhu Mali Veshaja Uddyan' was also established. An aphid host plant garden was also near this plant rescue centre. Pictures of some species both invasive and native, transplantation of traditional mango germplasm and medicinal garden are given as separate figures. 


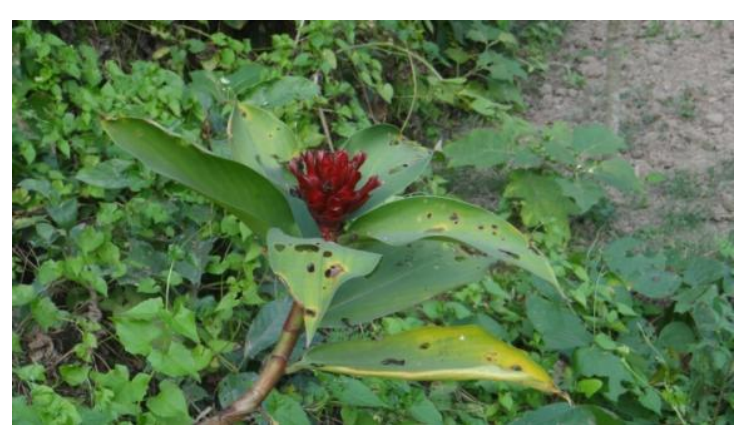

Fig 1. Costus speciosus (Konig) Smith.

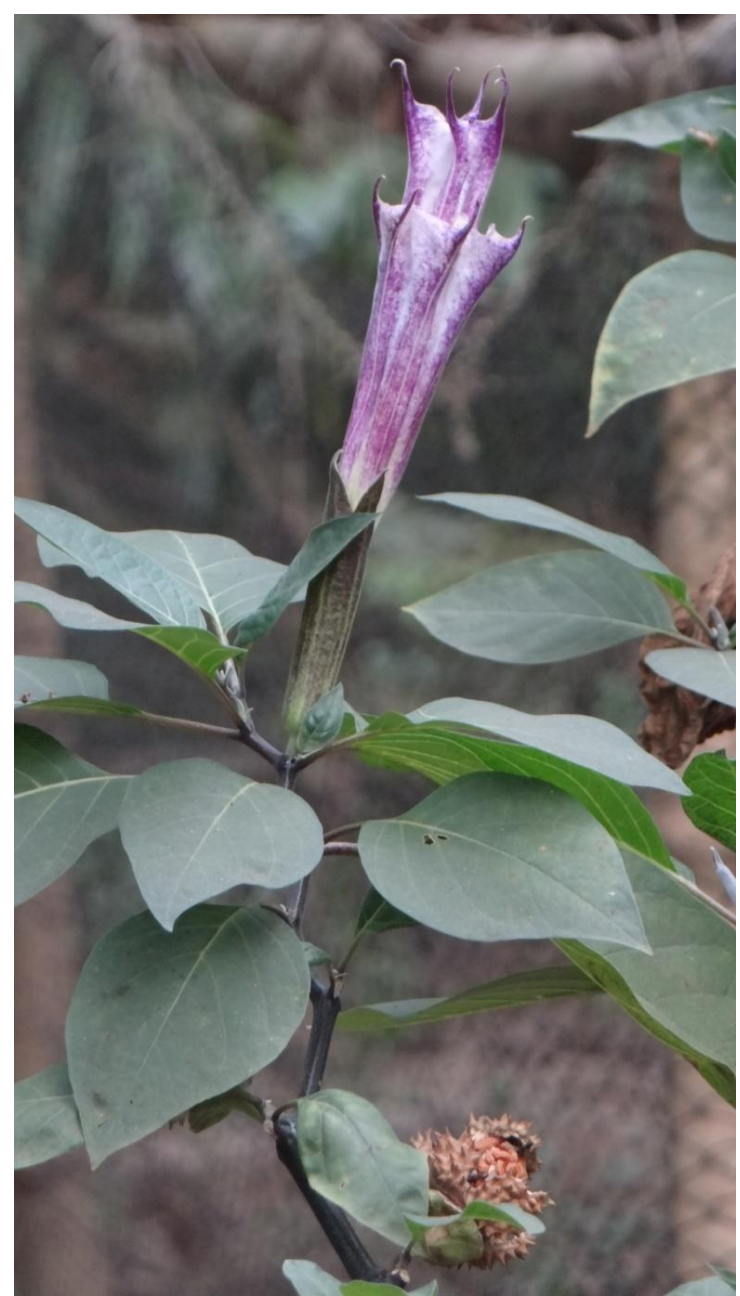

Fig 2. Datura mete/ L.

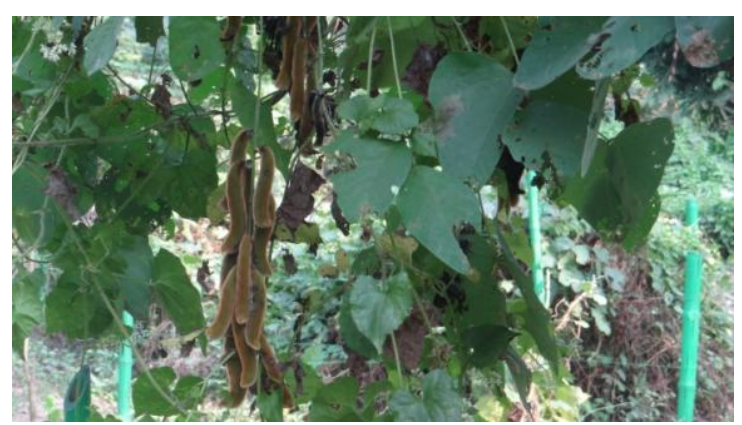

Fig. 3 Mucuna puriens (L) DC.

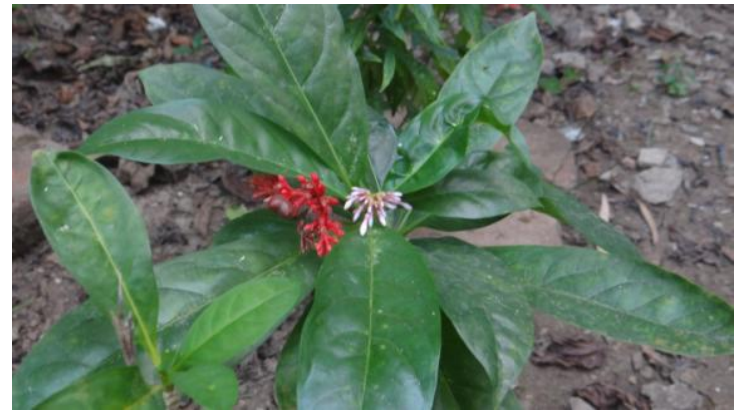

Fig 4. Rauvolfia serpentina Benth.

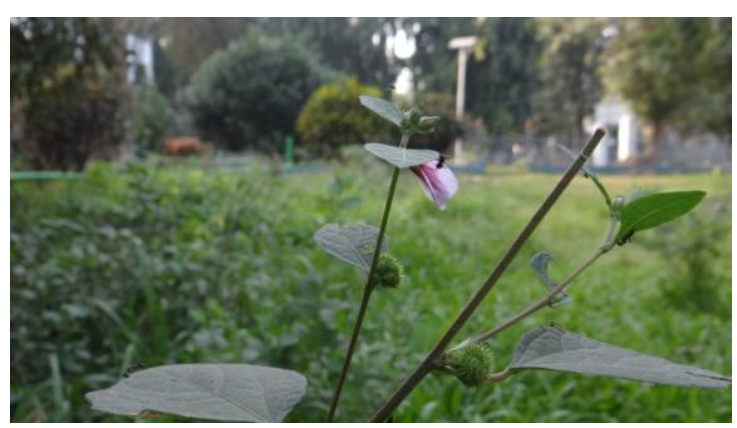

Fig. 5. Urena lobata L.

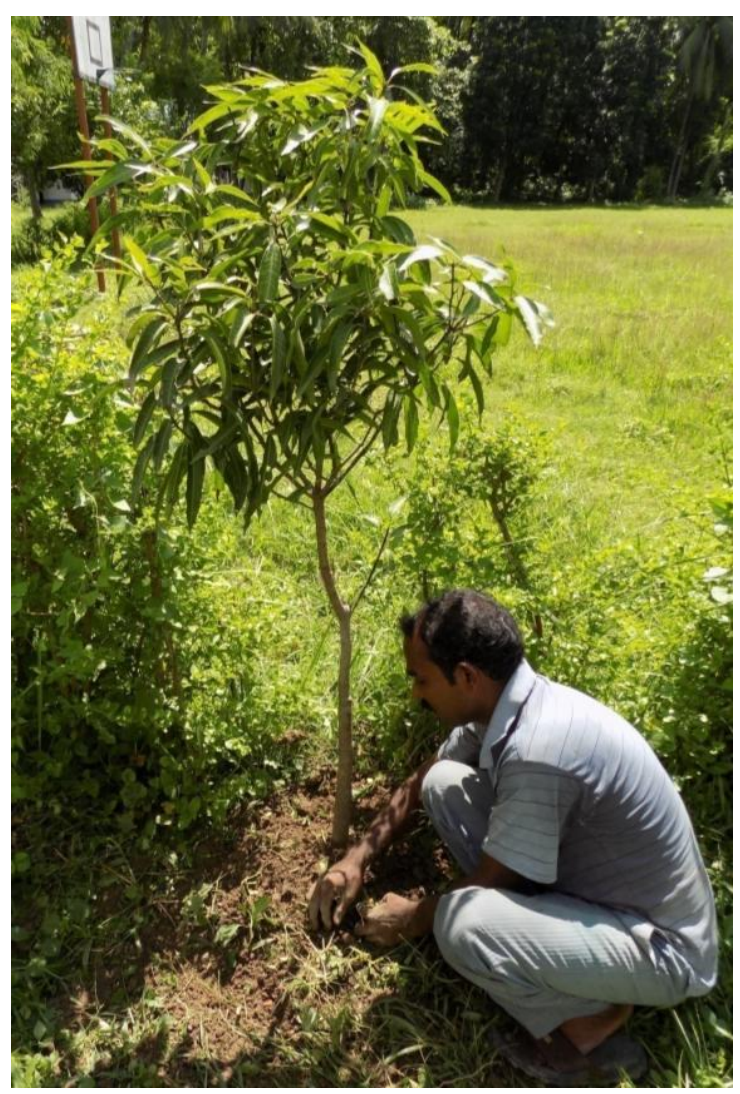

Fig. 6 Traditional mango variety sapling planting in college campus 
Int J Adv Life Sci Res. Volume 2(3) 01-10

Pal et. al.

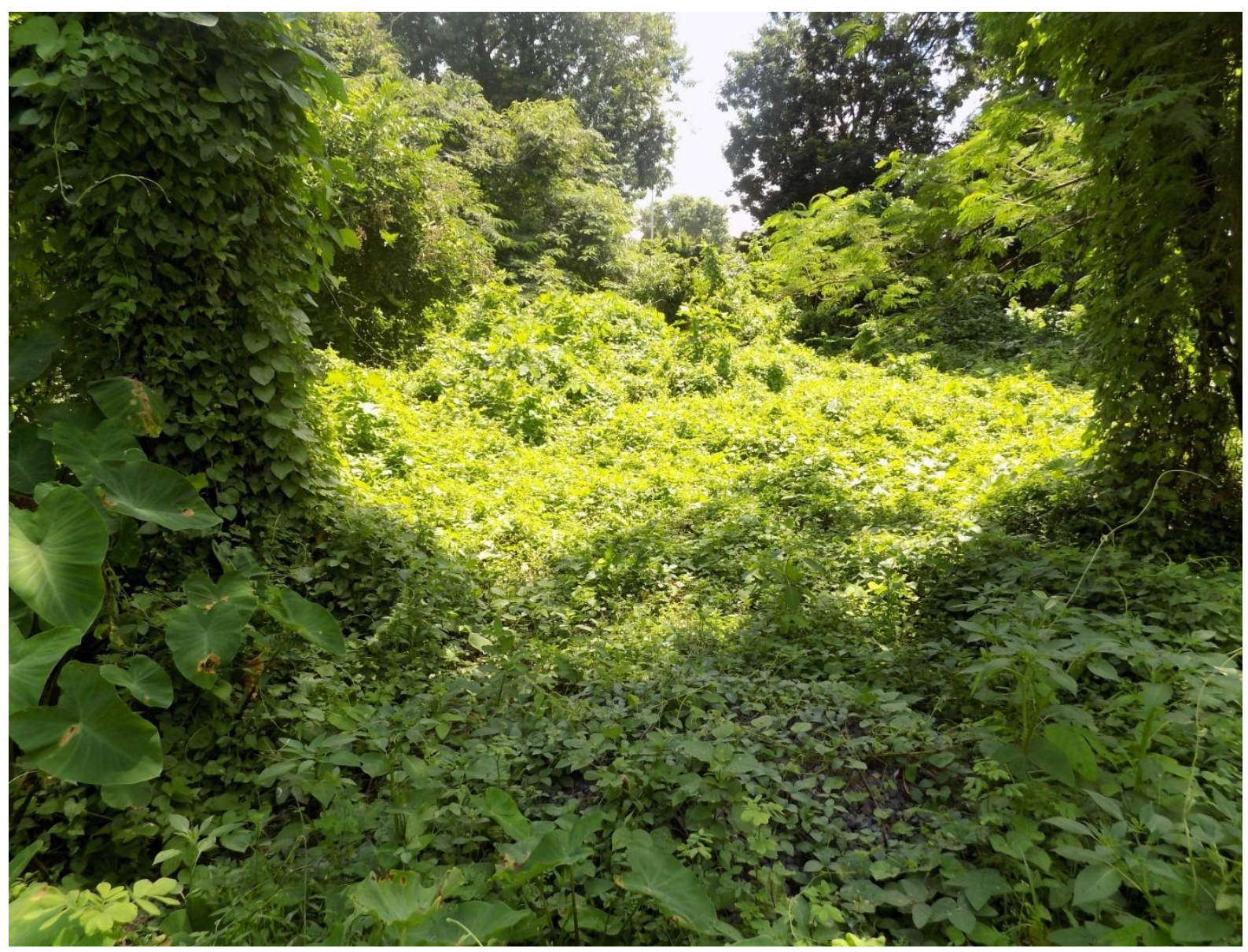

Fig. 7. A part of the Plant Rescue Centre

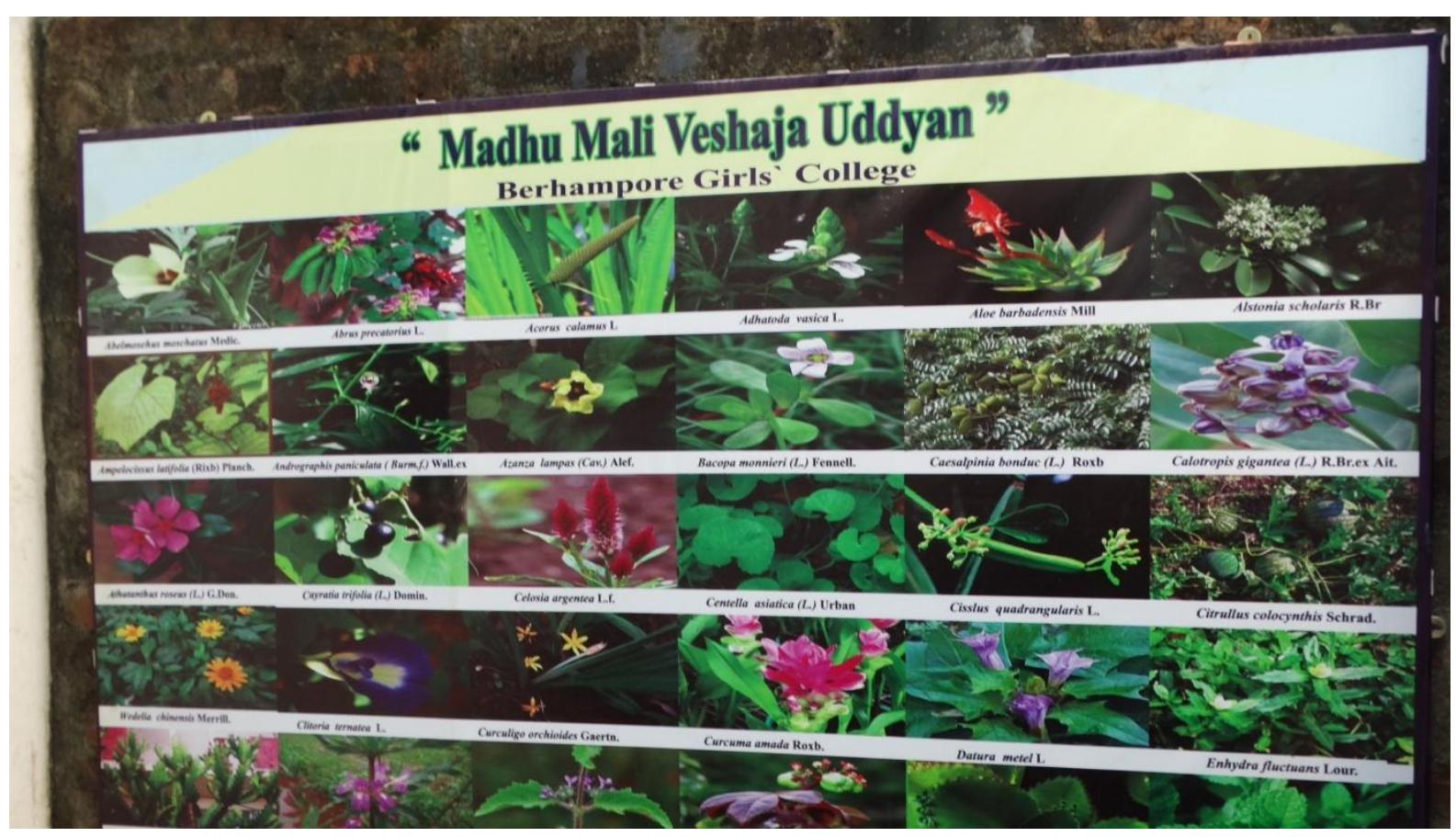

Fig. 8. Medicinal Garden at Berhampore Girls' College 
Table 1. Species diversity, relative frequency, density and abundance of individual species recorded.

\begin{tabular}{|c|c|c|c|c|}
\hline $\begin{array}{l}\text { Sl. } \\
\text { No. }\end{array}$ & Scientific Name & $\begin{array}{c}\text { Relative } \\
\text { frequency }\end{array}$ & Density & Abundance \\
\hline 1 & Abutilon indicum (L.) Sweet & 100 & 1.7 & 1.7 \\
\hline 2 & Acalypha indica L. & 100 & 3.5 & 3.5 \\
\hline 3 & Achyranthes aspera Linn. & 100 & 2.9 & 2.9 \\
\hline 4 & Ageratum conyzoides Linn. & 80 & 1.4 & 1.8 \\
\hline 5 & Alternanthera sessilis (L.) R. Br. ex DC. & 100 & 3.3 & 3.3 \\
\hline 6 & Alternanthera paronychioides A.St.-Hil. & 90 & 2.5 & 2.8 \\
\hline 7 & Alternanthera philoxeroides (Mart.) Griseb. & 80 & 1.7 & 2.1 \\
\hline 8 & Andrographis paniculata (Burm. F.) Wall. Ex Nees & 90 & 1.3 & 1.4 \\
\hline 9 & Argemone mexicana Linn. & 20 & 0.5 & 2.5 \\
\hline 10 & Barleria pronitis L. & 100 & 1.4 & 1.4 \\
\hline 11 & Blumea lacera (Burm.f.) DC. & 100 & 2.1 & 2.1 \\
\hline 12 & Boerhaavia repens Linn. & 100 & 2.8 & 2.8 \\
\hline 13 & Cardiospermum halicacabum L. & 10 & 0.1 & 1.0 \\
\hline 14 & Cassia tora L. & 100 & 1.9 & 1.9 \\
\hline 15 & Cassia sophera L. & 80 & 1.3 & 1.6 \\
\hline 16 & Catharanthus roseus (L.) G. Don. & 30 & 0.8 & 2.7 \\
\hline 17 & Chloris barbata Sw & 40 & 1.6 & 4.0 \\
\hline 18 & Chrozophora plicata (Vahl) A. Juss. ex Spreng & 80 & 1.4 & 1.8 \\
\hline 19 & Cleome viscosa $\mathrm{L}$. & 100 & 1.7 & 1.7 \\
\hline 20 & Coccinia grandis (L.) Voigt & 100 & 1.5 & 1.5 \\
\hline 21 & Commelina benghalensis L. & 80 & 1.3 & 1.6 \\
\hline 22 & Desmodium gyrans $\left(\mathrm{L}_{\mathrm{f}}\right) \mathrm{DC}$ & 90 & 1.4 & 1.6 \\
\hline 23 & Dracaena spicata Roxb. & 30 & 0.3 & 1 \\
\hline 24 & Echinochloa colona (L.) Link & 90 & 1.6 & 1.8 \\
\hline 25 & Eclipta alba Hassak L. & 100 & 2.3 & 2.3 \\
\hline 26 & Hygrophila schulli (Ham.) M.R. \& S.M. Almeida & 50 & 0.7 & 1.4 \\
\hline 27 & Ipomoea carnea Jacq. & 40 & 0.5 & 1.3 \\
\hline 28 & Leucas linifolia (Roth.) Spreng. & 100 & 1.5 & 1.5 \\
\hline 29 & Lantana camara Linn. & 100 & 2.2 & 2.2 \\
\hline 30 & Lindenbergia indica (L.) Vatke & 100 & 2.1 & 2.1 \\
\hline 31 & Mucuna puriens (L) DC. & 50 & 0.6 & 1.2 \\
\hline 32 & Oxalis corniculata Linn. & 100 & 2.2 & 2.2 \\
\hline 33 & Oldenlandia corymbosa $\underline{\text { L. }}$ & 100 & 3.3 & 3.3 \\
\hline 34 & Parthenium hysterophorus L & 80 & 1.5 & 1.9 \\
\hline 35 & Rauvolfia serpentina Benth. & 100 & 1.6 & 1.6 \\
\hline 36 & Rauwolfia tetraphylla L. & 80 & 1 & 1.3 \\
\hline 37 & Ruellia tuberose L. & 90 & 1.5 & 1.7 \\
\hline 38 & Scoparia dulcis L. & 30 & 0.5 & 1.66 \\
\hline 39 & Setaria glauca (L.) Beauv. & 90 & 2.1 & 2.3 \\
\hline 40 & Sida acuta Burm.f. & 80 & 1.3 & 1.6 \\
\hline 41 & Sida cordifolia L. & 30 & 0.3 & 1 \\
\hline 42 & Solanum nigrum L. & 90 & 2 & 2.2 \\
\hline 43 & Solanum xanthocarpum Schrad. and Wendl. & 60 & 0.7 & 1.2 \\
\hline 44 & Triumfetta rhomboidea Jacq. & 40 & 1.6 & 4.0 \\
\hline 45 & Vernonia cinerea Less. & 90 & 2 & 2.2 \\
\hline
\end{tabular}

Mango Germplasm Conservation within the plant rescue centres: Murshidabad and Maldah are famous for its mango (Mangifera indica $\mathrm{L}$ ) varieties but this traditional germplasm is under threat due to anthropogenic reasons. The age old plants are usually low yielding, and are being replaced by new high yielding hybrids. The plant rescue centre that had been established also became areas designated for conservation of the traditional mango varieties of Malda and Miushidabad, 
Some of the traditional mango variety saplings were planted in the Berhampore Girls' College campus as ex situ conservation measure. The names of the mango varieties are as follows: Aswina, Bhabani,
Bimli, Chinichampa, Chotolakshman, Dilswad, Guti, Madhuchuski, Madhugulguli, Molamjam, Nawabbhog, Rakhalbhog Sarengi, Shadulla, Surikhas.

Table 2. List of invasive weeds observed during the quadrat study

\begin{tabular}{|c|c|c|c|}
\hline $\begin{array}{l}\text { SI. } \\
\text { No. }\end{array}$ & Scientific Name & Family & Place of origin \\
\hline 1 & Acalypha indica L. & Euphorbiaceae & South Africa \\
\hline 2 & Ageratum conyzoides Linn. & Asteraceae & Tropical America \\
\hline 3 & Alternanthera sessilis (L.) R.Br. ex DC. & Amaranthaceae & Trop. Central.\& S America. \\
\hline 4 & Alternanthera paronychioides A.St.-Hil. & Amaranthaceae & Trop. Central.\& S America. \\
\hline 5 & Alternanthera philoxeroides (Mart.) Griseb. & Amaranthaceae & Trop. Central.\& S America. \\
\hline 6 & Argemone mexicana Linn. & Papavaraceae & Trop. Central.\& S America. \\
\hline 7 & Blumea lacera (Burm. f.) DC. & Asteraceae & Tropical America \\
\hline 8 & Catharanthus roseus (L.) G. Don. & Apocynaceae & Madagascar \\
\hline 9 & Cassia alata Linn. & Fabaceae (s.l) & West Indies \\
\hline 10 & Cassia obtusifolia L. & Fabaceae (s.l) & Tropical America \\
\hline 11 & Chromolaena odorata (L.) King \& Rob. & Asteraceae & Tropical South America \\
\hline 12 & Cleome viscosa $\mathrm{L}$ & Capparidaceae & Tropical America \\
\hline 13 & Costus speciosus (Konig) Smith. & Costaceae & Malay Peninsula \\
\hline 14 & Cyperus rotandus Linn. & Cyperaceae & Africa/Southern Europe \\
\hline 15 & Datura metel Linn. & Solanaceae & Tropical America \\
\hline 16 & Datura stramonium L. & Solanaceae & Tropical America \\
\hline 17 & Echinochloa colona (L.) Link & Poaceae & Tropical South America \\
\hline 18 & Eclipta prostrate (L.) Linn. & Asteraceae & Tropical America \\
\hline 19 & Kalanchoe pinnata (Lam.) Pers. & Crassulaceae & Madagascar/Southern Africa \\
\hline 20 & Lantana camara Linn. & Verbenaceae & Tropical America \\
\hline 21 & Mimosa pudica Linn. & Fabaceae (s.l) & Brazil \\
\hline 22 & Mucuna puriens (L) DC. & Fabaceae & Africa/Tropical Asia \\
\hline 23 & Oxalis corniculata Linn. & Oxalidaceae & Europe \\
\hline 24 & Parthenium hysterophorus $\mathrm{L}$ & Asteraceae & Mexico \\
\hline 25 & Scoparia dulcis Linn. & Scrophulariaceae & Tropical America \\
\hline 26 & Sida acuta Burm.f. & Malvaceae & Tropical America \\
\hline 27 & Synedrella nodiflora Gaertn. & Asteraceae & West Indies \\
\hline 28 & Tridax procumbens Linn. & Asteraceae & Trop. Central America \\
\hline 29 & Triumfetta rhomboidea Jacq. & Tiliaceae & Trop. America \\
\hline 30 & Urena lobata Linn. & Malvaceae & Trop. Africa \\
\hline 31 & Xanthium strumarium Linn. & Astercaceae & Trop. America \\
\hline
\end{tabular}

Table 3. List of native weeds some newly introduced and conserved in the plant rescue centres within the college campus

\begin{tabular}{|l|l|c|c|c|}
\hline $\begin{array}{l}\text { Sl. } \\
\text { No. }\end{array}$ & Scientific Name & Family & $\begin{array}{c}\text { Common Name in } \\
\text { English }\end{array}$ & $\begin{array}{c}\text { Common Name in } \\
\text { Bengali }\end{array}$ \\
\hline 1 & $\begin{array}{l}\text { Andrographis paniculata (Burm. F.) } \\
\text { Wall. Ex Nees }\end{array}$ & Acanthaceae & Creat & Kalmegh \\
\hline 2 & Asparagus racemosus Willd & Asparagaceae & Climbing asparagus & Shatamuli \\
\hline 3 & Barleria pronitis L. & Acanthaceae & Porcupine flower & Kantajanti \\
\hline 4 & Boerhaavia repens Linn. & Nyctaginaceae & Spreading Hog-weed. & Punarnaba \\
\hline 5 & Centella asiatica (L.) Urb. & Apiaceae & Asiatic pennywort & Thankuni \\
\hline 6 & Clerodendrum viscosum Vent. & Verbenaceae & Hill glory bower & Ghetu \\
\hline 7 & Cissus quadrangularis L. & Vitaceae & Devil's backbone & Harjora \\
\hline 8 & Colocasia esculenta (Linn.) Schott & Araceae & Arum & Kochu \\
\hline 9 & Desmodium gyrans (Lf) DC & Fabaceae & Indian Telegraph Plant & Bonchandal \\
\hline 10 & $\begin{array}{l}\text { Hygrophila schulli (Ham.) M.R. \& } \\
\text { S.M. Almeida }\end{array}$ & Acanthaceae & Marsh Barbel & Kulekhara. \\
\hline 11 & Leucas linifolia (Roth.) Spreng. & Lamiaceae & Head Leucas & Swetdron \\
\hline 12 & Ocimum tenuiflorum L. & Lamiaceae & Holy Basil & Tulsi \\
\hline 13 & Rauvolfia serpentina Benth. & Apocynaceae & Indian snake root & Sarpagandha \\
\hline 14 & Rauwolfia tetraphylla L. & Apocynaceae & Wild snake root & Bar Chandrika \\
\hline
\end{tabular}




\section{Discussion:}

The survey of plant diversity is very much important because it provides baseline information for comparison after modification of the habitats and to monitor changes in biodiversity overtime. Survey results are useful to determine the presence of rare, threatened, exotics, natives, pest and medicinal plant species (Md. Zashim Uddin and Md. Abul Hassan. 2016). The frequency values differ in different communities. They are influenced by micro-habitat conditions, topography, soil and many other environmental characteristics. Unless frequency is not correlated with other characters such as density, frequency alone does not give correct idea of the distribution of a species. Many species having low population density also rate low in frequency, but some may have high frequency because of their uniform distribution. Usually if the population density is high, the frequency will be high. The plants with high frequency are wide in distribution. Extensive work on the development of vegetation depends upon good indigenous vegetation recovery. The indigenous mango varieties that were planted would help in vegetation recovery by providing shade and canopy to other plant species. Preservation of these communities especially within disturbed sites is more generally, demands a unique and pressing conservation challenge (lqbal et al, 2008).

\section{Conclusion}

Species diversity is considered to be an important attribute of community organization and allowed comparison of the structural characteristics of the communities. It is often related to community dynamics stability,

\section{References}

Ayyappan N and Parthasarathy N, (1999).Biodiversity inventory of trees in a large-scale permanent plot of tropical evergreen forest at Varagalaiar, Anamalais, Western Ghats, India. Biodiversity and Conservation, 8(11), pp.1533- 1554.

Chen B, Kang L (2003) Biological invasion and its relation with global changes. Chin J Ecol 22(1), pp.31-34.

Celesti-Grapow, L., P. Pyšek, V. Jarošík \& C. Blasi (2006). Determinants of native and alien species productivity, integration, evolution, structure and competition. Due to construction work in educational campuses the local flora are often threatened (Iqbal et al, 2008). Plant ecological surveys of all the disturbed and threatened areas on permanent basis are required to know their current biodiversity situation and future continuity status. Plantation of indigenous plants is necessary. The present study concludes that conservation of identified species within the plant rescue centres is important. At present the most crucial problem is habitat loss due to interference of human activity and fragmentation due to various developmental projects in the campus. The plant rescue centres would provide areas undisturbed by anthropogenic disturbances. Given adequate time there would be ecological restoration. However one has to be vigilant about competitive invasive species. If required the indigenous plants must be provided with additional care. It is also important that floristic and/or structural inventories be performed not only over particular areas but also over time.

\section{Conflicts of Interest}

The authors declare that there are no conflicts of interest regarding the publication of this work.

\section{Acknowledgement}

This work has been carried out with the financial assistance of a Research Project of the West Bengal Biodiversity Board (WBBB) to the first author as Principal investigator. The authors would also like to express their thanks to the Principal, Berhampore Girls' College, Berhampore, Murshidabad, India for providing laboratory facilities to conduct this study.

richness in the urban flora of Rome. Diversity and Distributions 12(5), pp. 490-501.

Corlett RT (1988) The naturalized flora of Singapore. Journal of Biogeography 15, pp. 657-63.

Larson, Diane L. (2003). Native weeds and exotic plants: relationships to disturbance in mixed-grass prairie. Plant Ecology, Volume 169, Number 2, Page 317-333.

Harlan, J.R., (1992). Crops and management. 2nd Edn American Society of Agronomy. Madison, WI. 
Hobbs R.J. and Humphries S.E. (1995). An integrated approach to the ecology and management of plant invasions. Conservation Biology 9, pp 761-770.

Iqbal, Muhammad, Zafar ; Shah, S. Z.; Shafiq, M. (2008). Ecological surveys of certain plant communities around urban areas of Karachi . J. Appl. Sci. Environ. Manage. 12(3) 51, pp. 60.

Isbell F, Tilman D, Polasky S, Loreau M. (2015). The biodiversity-dependent ecosystem service debt. Ecology Letters 18, pp.119-134.

Jana B. 2016. Common Invasive Medicinal Plant Species in East Midnapore District, West Bengal, India. Ann Clin Lab Res. 4:1.

Kent, M. and Coker, P. (1992). Vegetation Description and Analysis. A Practical Approach. John Wiley and Sons, Chichester, England.

Leblanc, M. L. and M. L. Cloutier .(2001). Susceptibility of row-planted soybean (Glicine max) to the rotary hoe. Journal of Sustainable Agriculture 18, pp. 53-62.
Md. Zashim Uddin and Md. Abul Hassan. 2016. Plant Diversity of Dhaka University Campus. J. Asiat. Soc. Bangladesh, Sci. 42(1), pp.49-68 pp.

Moolani, M. K., and Sachan, P. L. (1966). Studies on crop weed competition - A Review. Journal of Agronomy 11,pp.372-377.

Moreno-Mateos, David et al. (2017). Anthropogenic ecosystem disturbance and the recovery debt. Nature Communications, 8, pp.14163.

Morgenthal, T.L.; Cilliers, S.S.; Kellner, K.; Hamburg, H.V.; Michael, M.D. (2001). The vegetation of ash disposal sites at Hendrina Power Station II: Floristic composition. South African Journal of Botany 67 (4), pp. 520 - 532.

Pickett S.T.A. and White P.S. (1985). The Ecology of Natural Disturbance and Patch Dynamics. Academic Press, Inc., San Diego, California, USA.

Raunkiaer, C. (1934). The Life form of Plants and Statistical Plant Geography. The Clarendon Press, Oxford.

Reddy Sudhakar, C. (2008). Catalogue of Invasive Alien Flora of India. Life Science Journal. 5, pp.84-89. 